HASAN MALAY

UDC: 003.341

Izmir, Turkey

MARIJANA RICL

University of Belgrade, Serbia

\title{
TWO NEW EARLY-HELLENISTIC INSCRIPTIONS FROM AIOLIS AND KARIA
}

\begin{abstract}
Two new Hellenistic inscriptions from Aiolian Aigai and northern Karia are presented on this occasion. The stele from Aigai preserves about a half of a civic decree alluding to the friendship with an unknown community and its renewal under the same conditions as those existing between Aigai and Kadya-. The inscription from northern Karia dates from the reign of Ptolemy II or III and registers a vow to Dionysos on behalf of the King by a previously unattested commander of a Ptolemaic garrison and his soldiers.
\end{abstract}

Dedicated to the Memory of Professor Fanula Papazoglu, With Eternal Gratitude

1. Stele of local hard brownish stone broken on top, on the right side and below, preserved on the left side, and containing currently 17 lines engraved in stoichedon-style, with originally 23 letters per line (cf. on lines 6 and 7 below), while today the best preserved line (11) contains only twelve letters. Dim.: Height 62, width 31, thickness $12.5 \mathrm{~cm}$; letters from 1.5 to $2 \mathrm{~cm}$. Alpha with a straight crossbar; Theta, Omicron, Omega smaller (average 1-2 cm) than the other letters and carved above the line; Sigma with tilted upper and lower bars; Epsilon with a shorter crossbar; Kappa with short divergent bars; $M y$ with splayed legs; the right verticals of $N y$ and $P i$ not reaching the baseline. The stone was found near Aigai (Köseler) ${ }^{1}$ and transported to the Manisa Museum in 1995. No inventory number.

Date: $3^{\text {rd }}$ century B.C.

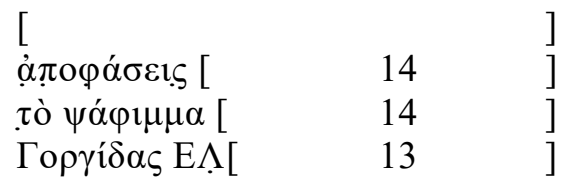

${ }^{1}$ For a bibliography on Aigai see H. Malay - M. Ricl, EA 42, 2009, p. 42, note 5. 


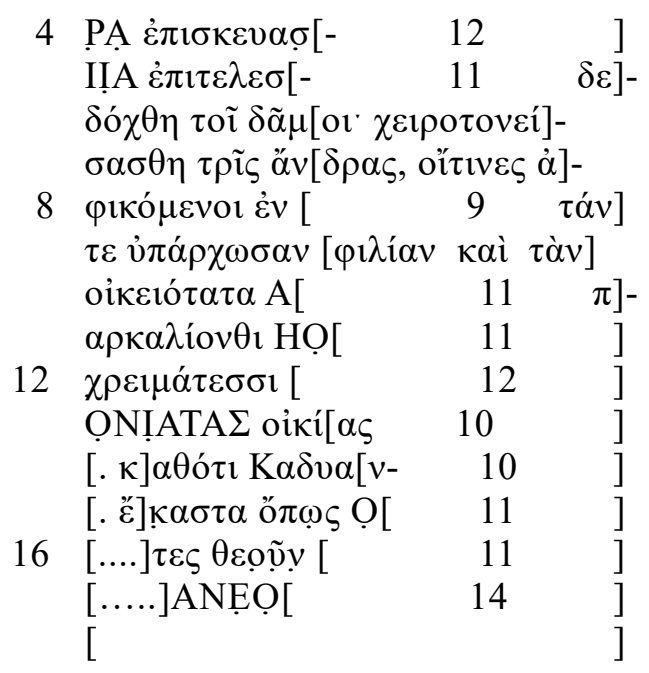

1 The first two letters of this line can barely be recognized on the squeeze and the fourth $(P h i)$ and last letter (Sigma) are not as clear as one would wish; nevertheless, we are confident that our reading is correct.

2 For the form $\psi \alpha \dot{\alpha} \varphi \mu \mu \alpha \mathrm{cf}$. H. Malay, Greek and Latin Inscriptions in the Manisa Museum (ETAM 19), 1993, no. 515 (fragmentary decree from Aigai). It is also attested on Crete (IC I XVII 2 and 6).

3 The letters E $\Lambda$ could be the beginning of Gorgidas' patronymic (adjective).

4 The first two letters of the line are damaged beyond recognition: the first could be a Rho, the second Alpha.

5 If the first letter of this line is Eta, one could propose the reading $\tau \grave{\alpha} \chi \rho] / \eta \dot{\alpha}$ $\dot{\varepsilon} \pi \imath \varepsilon \lambda \varepsilon \sigma[-$ 'fulfilled his duties'.

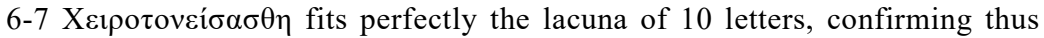
the count of twenty-three letters per line (cf. the following commentary).

7 Since there can hardly be any doubt on how to restore this line, we can conclude that the original number of letters per line was twenty-three. This is additionally confirmed by the certain supplements in line 9 and the plausible one in line 6 .

11-12 The last preserved letter in line 11 looks like a Theta, Omicron or Omega.

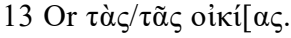

14 Cf. the from $\kappa \alpha \tau \tau$ ó $\imath$ in K. Schuchhardt in: R. Bohn, Altertümer von Aegae. JDAI, $\operatorname{ErgH~2,~1889.~IV:~Die~Inschriften,~p.~} 42$.

15 The right half of $\mathrm{K}[., \varepsilon] \kappa \alpha \sigma \tau \alpha$ can be seen on the squeeze; - in Aigai we also find the previously documented form őкоббov in J. Keil - A. von Premerstein. Bericht über eine Reise in Lydien und der südlichen Aiolis, ausgeführt $1906 \mathrm{im}$ Auftrage der Kaiserlichen Akademie der Wissenschaften, Kaiserliche [Österreichische] Akademie der Wissenschaften, Philosophisch-historische Klasse, Denkschriften [DAW], 53, 2, Vienna 1908, p. 97 no. 203 line 8; - it is not absolutely certain that the last letter in this line is an Epsilon or the third one from the end an Omega.

16 Only the first two letters in this line are certain, the third could be either Epsilon or Kappa: if what originally stood on this part of the stone was ANKON, we

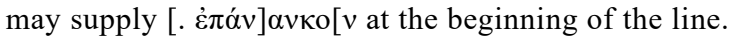

17 The text of the inscription continued beyond this line for another 5-6 lines until the preserved lower end of the stone, but only a couple of letters are recognizable here and there. 

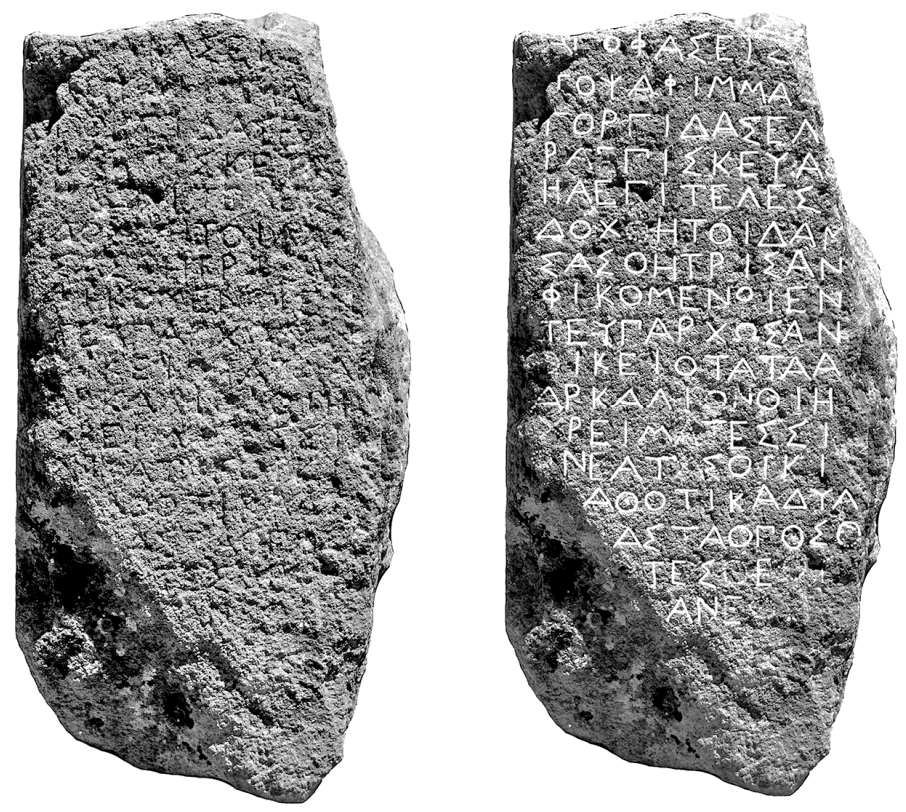

Translation:

"... decisions... the decree... Gorgidas... having repaired... completed... it was decreed by the people [to elect] three men [who], upon arrival in..., [having renewed the] existing [friendship and] familiarity, will propose... property... (the?) house(s)... as for Kadya[n-...] ... everything, so that?... gods? ...".

The new stele preserves less than a half of a decree issued by the city of Aigai that originally contained praise (?) for one Gorgidas (a foreign architect ?) and a decision to send three ambassadors to his home city (?) to renew the friendship and intimacy existing between the two communities and to propose the conclusion of a treaty on ateleia and asylia (?) between them under the same conditions as those existing between Aigai and Kadya-. Due to the unsatisfactory state of preservation of the inscription, this interpretation remains hypothetical. The decree was most probably inscribed in the course of the $3^{\text {rd }}$ century B.C. when Aigai stood under the rule of the Seleucids.

1 It remains unknown who made the decisions/verdicts mentioned in the first line and what they referred to.

2 The decree referred to in this line could have been issued by the citizens of Aigai when they decided to carry out some reconstruction works in their city.

3 Gorgidas seems to have been an architect (?) active in some building projects in Aigai involving reconstruction, perhaps after an earthquake or a war whose exact nature and circumstances escape us. 
4 Unknown building(s) were reconstructed and the rest of the works completed in a satisfactory manner.

10 On the concept of oiketó $\rceil \zeta$, cf. E. Will, Syngeneia, Oikeiotes, Philia, RPh 1995 [1997], 299-325; A. Erskine, Delos, Aeneas and IG XI.4.756, ZPE 117, 1997, 133-136; R. Sammartano, Sul concetto di oikeiotes nelle relazioni interstatali greche, in G. Daverio Rocchi (ed.), Tra concordia e pace. Parole e valori della Grecia antica, Milano 2007, 207-235 (non vidimus); C.P. Jones, "Kinship (syngeneia) in Two Cities of the Troad", Chiron 40, 2010, 29-39. After oikeıó $\tau \alpha \tau \alpha$ one expects a form of the verb $\alpha v \alpha v \varepsilon$ ó $\mu \alpha$, but in the Aiolian dialect $\dot{\alpha} v \alpha$ - becomes ỏv-. Perhaps we can supply $\dot{\alpha}[\mu \mu \varepsilon \dot{\varepsilon} \omega v$ ? In any event, there is no doubt about the meaning of this line.

11 This line contained a part of the proposal that was to be made by the ambassadors of Aigai to the citizens of the unknown city upon their arrival.

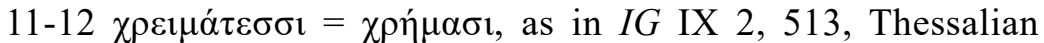
Larissa, III B.C., where a group of people is granted ateleia, isotimia, epinomia, asylia in war and peace for themselves and their movable

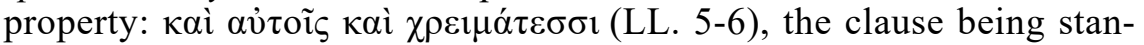
dard in similar grants all over the Greek world.

13 The context in which houses are mentioned here remains un-

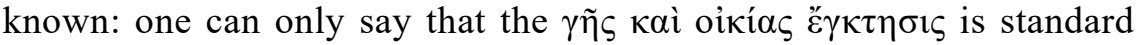
in proxeny decrees. Along the same lines, if a word akin to ỏvátaৎ or कैvia is hiding in the first seven letters, it could be a question of real estate commerce or market wares in general. Yet another, less likely possibility is that in lines 6-7 we should read: $\kappa] /$ ovió $\tau \alpha \varsigma$ oikías "plastered houses".

14 The expected treaty between Aigai and the unknown city seems to be compared to the one previously concluded between Aigai and $\mathrm{K} \alpha \delta v \alpha[-$. The fragmentary ethnic name can be supplied as K $\alpha \delta v \alpha-$

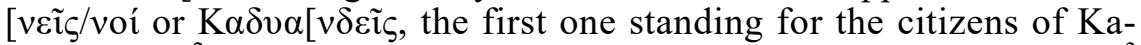
doi $(\text { Gediz) })^{2}$ in Mysia, the second one for the citizens of Kadyanda ${ }^{3}$

${ }^{2}$ For the city of Kadoi, placed by ancient authors in Mysia (Mysia Abbaitis in OGI 446), Phrygia Epiktetos or Maionia cf. RE 1941, col. 794 (W. Ruge); Chr. Habicht, "New Evidence on the Province of Asia", JRS 65, 1975, 65 (BE 1976, 595;

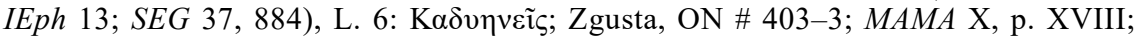
M. Waelkens, Die kleinasiatischen Türsteine. Typologische und epigraphische Untersuchungen der kleinasiatischen Grabreliefs mil Scheintür, 1986, 35-37; G. M. Cohen, The Hellenistic Settlements in Europe, the Islands, and Asia Minor, 1995, 213-214; G. Petzl - C. Tanriver, "Grabgedicht für eine geliebte Stiefmutter", EA 36, 2003, 24-

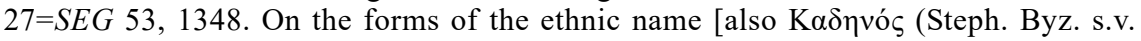

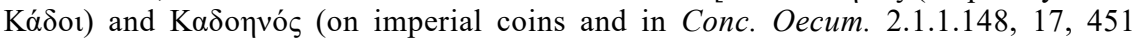
A.D.)] cf. Habicht, op. cit. 73. The city started its life as a Macedonian colony (Pliny NH V 111: Macedones Cadieni); contra Habicht, Cohen. The original name of the

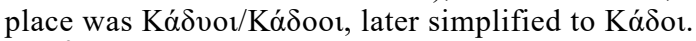

${ }^{3}$ A citizen of Kadyanda is on record in an inscription from Paphos dated in 224/3 BC (SEG 20, 174). Cf. Zgusta, ON \# 403-1. 
(Fethiye/Üzümlü) in Lykia. Although it cannot be ruled out that Aigai and Kadyanda had some kind of treaty on asylia and ateleia, we think it more reasonable to assume the existence of such a treaty with a city closer to Aigai. ${ }^{4}$

If this is true, then the existence of Kadoi is pushed back in time considerably, since up to now the two earliest mentions of the place were in a letter from Eumenes II dated in 165/4 BC and mentioning the Mysians in Kadooi ${ }^{5}$, and in Polybios $(33,12,2)$, who names Kadoi as the meeting point of Attalos II and Roman ambassadors in 154 B.C., during a war between Attalos and Prusias II $^{6}$.

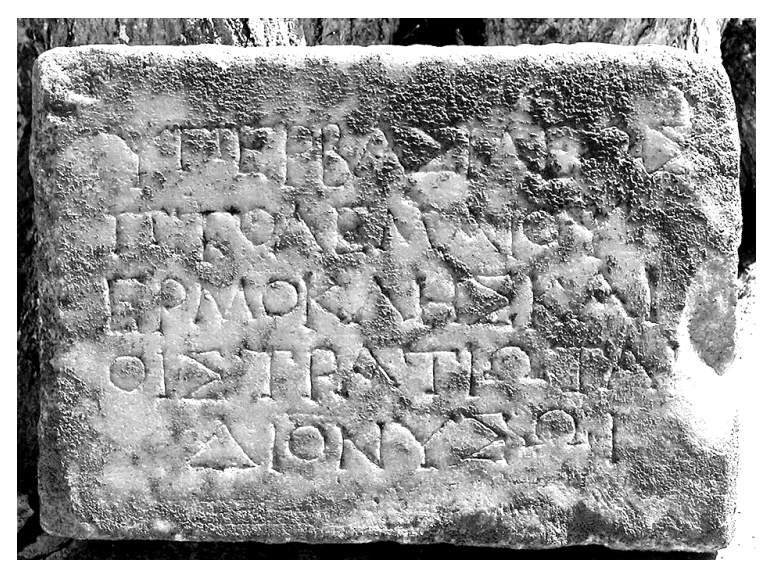

2. Plaque of white marble. Exact find-spot unknown, kept in the private collection of Doğu Bayazit in Germencik (Inv. Nr. 27) ${ }^{\dagger}$. According to the owner, the stone was brought from Bozdoğan (probably originating from ancient Bargasa situated some $13 \mathrm{~km}$ SE of Bozdoğan at

${ }^{4}$ We have evidence of a commercial treaty between Aigai and Olympenoi in J. Keil - A. von Premerstein. Bericht über eine Reise in Lydien und der südlichen Aiolis, ausgeführt 1906 im Auftrage der Kaiserlichen Akademie der Wissenschaften, Kaiserliche [Österreichische] Akademie der Wissenschaften, Philosophisch-historische Klasse, Denkschriften [DAW], 53, 2, Vienna 1908, p. 97 no. 203 lines 11-13. Cf. L. Robert, "Monnaies d'Olympos", Hellenica X, 1955, 178-187; J. Ma, "Grandes et petites cités au miroir de l'épigraphie classique et hellénistique", Topoi 18, 2013, 73-74; I. Savalli-Lestrade, "L'Éolide comme espace régional et construction culturelle", in: I. Savalli-Lestrade (ed.), L'Éolide dans l'ombre de Pergame, Topoi Suppl. 14, 2016, 21.

${ }^{5}$ P. Herrmann - H. Malay, New Documents from Lydia, Österreichische Akademie der Wissenschaften, philosophisch - historische Klasse, Denkschriften, 340. Band, Ergänzungsbande zu den Tituli Asiae Minoris, no. 24, Wien 2007, 49, no. 32A,

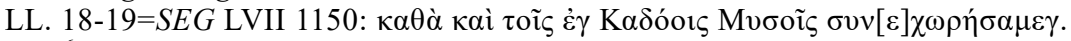

${ }^{6}$ On this war and the literary sources for it see Chr. Habicht, The Hellenistic Monarchies. Selected Papers, 2006, 12-21 (originally published in Hermes 84, 1, 1956, 90110).

${ }^{7} \mathrm{H}$. Malay expresses his deep thanks to Mr. D. Bayazit for his kind permission to publish the epigraphic material from his collection and for the hospitality during his work (in 2002) on the inscriptions. 
modern Çamlıdere/Haydere $)^{8}$. Dim.: Height 15.5, width 22, thickness $3.7 \mathrm{~cm}$; letters from 1.2 to $1.5 \mathrm{~cm}$.

Date: reign of Ptolemy II or III (281-222 B.C.).

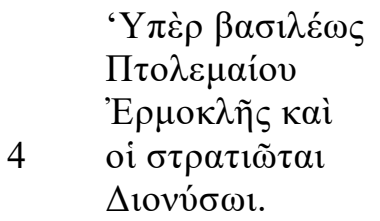

3 Hermokles is a previously unattested commander of a Ptolemaic garrison at Bargasa.

\section{Translation:} Dionysos".

"On behalf of (the) King Ptolemy, Hermokles and the soldiers to

The new dedication brings significant information on the geographical extent of the Ptolemaic "province of Karia". Another recently published inscription from the same region of Bargasa ${ }^{10}$ dating from the period of the war with Aristonikos, already showed that the

${ }^{8}$ On Bozdoğan in the lower valley of the Harpasos River, cf. W. R. Paton, "Sites in E. Caria and S. Lydia", JHS 20, 1900, 6. F. Ölmez published a $1^{\text {st }}$ century B.C. honorary inscription for a priest of Zeus Pigindenos from the site of the acropolis of Bargasa known locally under the name of Hisartepe ("Zeus Pigindenos Rahibi, Athenagoras Oğlu Aristodemos İçin Onur Yazıtı", Arkeoloji Dergisi 3, 1995, 165-166=SEG $45,1515)$. A monograph on the city is available in P. Debord - E. Varinlioğlu, Cités de Carie. Harpasa, Bargasa, Orthosia, 2010, 121-228, with, among others, new inscriptions featuring the same priest.

${ }^{9}$ On this topic see R. Bagnall, The Administration of the Ptolemaic Possessions outside Egypt, 1976, 89-102; A. Mastrocinque, La Caria et la Ionia meridionale in epoca ellenistica, 1979, 43-47 (non vidimus); G. M. Cohen, The Hellenistic Settlements in Europe, the Islands and Asia Minor, 1995, 53-54; J. Kobes, "Mylasa und Kildara in ptolemäischer Hand? Überlegungen zu zwei hellenistischen Inschriften aus Karien", EA 24, 1995, 1-6; H.-U. Wiemer, "Karien am Vorabend des 2. Makedonischen Krieges", EA 33, 2001, 10-11; R. van Bremen, "Ptolemy at Panamara", EA 35, 2003, 9-14; K. Mueller, Settlements of the Ptolemies. City Foundations and New Settlements in the Hellenistic World, 2006, 54; C. Marquaille, "The Foreign Policy of Ptolemy II" in P. McKechnie and P. Guillaume (edd.), Ptolemy II Philadelphos and his World, 2008, 46-48; A. Meadows, "The Ptolemaic Annexation of Lycia: SEG 27, 929" in The III rd Symposium on Lycia, Symposium Proceedings II, 2007, 464-466; idem, "Fouilles d'Amyzon 6 Reconsidered: The Ptolemies at Amyzon", ZPE 166, 2008, 115-120; idem, "Deditio in Fidem: The Ptolemaic Conquest of Asia Minor" in C. Smith and L.M. Yarrow (edd.), Imperialism, Cultural Politics and Polybius, 2012, 113-133.

${ }^{10}$ P. Briant - P. Brun - E. Varinlioğlu, Les cites d'Asie Mineure occidentale au IIe siècle, 2001, 241-259 (=SEG 51, 1495; An. Ép. 2001, 1911). 
city had a tribe called $\Pi \tau 0 \lambda \varepsilon \mu \alpha i \hat{\zeta}$, prompting its editors to the conjecture that it was founded by Ptolemy Philadelphos. The new inscription from Bargasa, currently the earliest one from the region, now confirms the conjecture of a Ptolemaic foundation. ${ }^{11}$

${ }^{11}$ An unpublished decree from Xystis in the Harpasos valley dated to the eleventh or twelfth year of Ptolemy son of Ptolemy (275/4 or 274/3 B.C.) and honouring a Ptolemaic officer (van Bremen, op. cit. 10, note 13) also demonstrates that the Ptolemaic control at its height stretched deep into the north and east of the Karian territory. 